\section{Asian \\ Journal of Instruction}

Asya Öğretim Dergisi

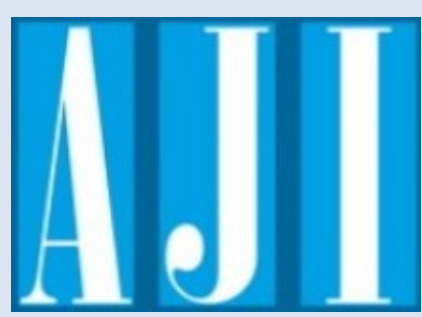

$2020,8(2), 52-63$

dergipark.gov.tr/aji

ISSN:2148-2659

Kabul Tarihi: 18/12/2020

Yayınlanma Tarihi: 26/12/2020

\title{
Fen Bilimleri Öğretmen Adaylarının Kök Hücreye Yönelik Algılarının Belirlenmesi
}

\author{
Metin Gönültaş ${ }^{1}$, Ebru Ezberci Çevik ${ }^{2}$, Emine Güneri ${ }^{3}$
}

Gönültaş, M., Ezberci Çevik, E., \& Güneri, E. (2020). Fen bilimleri öğretmen adaylarının kök hücreye yönelik algılarının belirlenmesi. Asya Öğretim Dergisi, 8(2), 52-63. https://doi.org/10.47215/aji.732735

\section{$\ddot{\mathbf{O} z}$}

$\mathrm{Bu}$ araştırmada, fen bilimleri öğretmen adaylarının biyoteknoloji konularından biri olan kök hücreye yönelik algılarının belirlenmesi amaçlanmıştır. Araştırmada nicel araştırma yönteminden tarama deseni kullanılmıştır. Araştırmada çalışma grubu, İç Anadolu Bölgesi'ndeki bir devlet üniversitesinin Eğitim Fakültesi Fen Bilgisi Eğitimi Ana Bilim Dalı'nda öğrenim gören 194 öğretmen adayından oluşmaktadır. Veri toplama aracı olarak “Kök Hücre Alg1 Ölçeği (KÖHAÖ)" kullanılmıştır. Beşli likert tipinde hazırlanan ölçeğin Cronbach Alfa değeri .864 olarak hesaplanmıştır. Verilerin analizinde betimsel istatistiklerden ve çıkarımsal istatistiklerden yararlanılmıştır. Araştırmanın sonucunda öğretmen adaylarının kök hücre algılarında cinsiyete göre anlamlı bir farklılık bulunmamıştır. Fakat sınıf düzeylerine göre adayların kök hücre algılarında anlamlı düzeyde farklılık belirlenmiştir. Ayrıca fen bilimleri öğretmen adaylarının kök hücre konusuna ilişkin algılarının ortalamanın üzerinde olduğu belirlenmiştir. Yapılan çalışma sonunda, öğretmen adaylarına ilgili konuda tümevarımsal bir öğretim süreci uygulanması, bunun yanında araştırmacıların farklı veri toplama araçlarıyla benzer çalışmalar yapmaları önerilmiştir.

Anahtar Kelimeler: Kök hücre, fen bilimleri öğretmen adayları, sosyobilimsel konular

\section{Determination of Science Teacher Candidates' Perception of Stem Cell}

\begin{abstract}
In this study, it was aimed to determine the perceptions of science teacher candidates towards stem cells, which is one of the biotechnology subjects. In the research, survey model, which is one of the quantitative research models, was used. The study group of the research consists of 194 prospective teachers studying at the Faculty of Education Science Education Department of a public university in the Central Anatolia Region. "Stem Cell Perception Scale (SCPS)" was used as data collection tool. The Cronbach Alpha value of the scale prepared in the five-likert type was calculated as $=.864$. Descriptive statistics and inferential statistics were used to analyze the data. As a result of the research, no significant difference was found regarding the perception of stem cells according to the gender of the teacher candidates. However, a significant difference was determined regarding the stem cells perceptions of the candidates according to the grade level. Besides, it was concluded that the science teacher candidates' perceptions of stem cells are above the average. At the end of the study, it was determined that the developed scale was a valid and reliable scale in determining the perceptions of teacher candidates about stem cells. Therefore, different studies can be used in the scale used in the study.
\end{abstract}

Keywords: Stem cells, science teacher candidates, socio-scientific issues

\footnotetext{
${ }^{1}$ Doktora Öğrencisi, Erciyes Üniversitesi, Eğitim Bilimleri Enstitüsü, ORCID: 0000-0002-2788-7620, gonultasmetin@gmail.com

${ }^{2}$ Dr. Öğr. Üyesi, Erciyes Üniversitesi, Eğitim Fakültesi, ORCID: 0000-0003-4219-3296, ezbercicevik@erciyes.edu.tr

${ }^{3}$ Prof. Dr., Erciyes Üniversitesi, Eğitim Fakültesi, ORCID: 0000-0002-3475-8229, eguneri@erciyes.edu.tr
} 
Fen Bilimleri Öğretmen Adaylarının Kök Hücreye Yönelik Algılarının Belirlenmesi

\section{Giriş}

Son zamanlarda bilim ile teknoloji hızlı bir şekilde gelişirken toplumda bilimin yeri önemli bir biçimde artmaktadır. Teknolojide yaşanan bu gelişmeler bilim ile toplumun ilişkisinin önemini ortaya çıkarmaktadır. Bu nedenle bilim ile toplum ilişkisini çeşitli yönlerden değerlendirmek gerekmektedir (Babacan, 2017). Bilim ile teknoloji arasındaki etkileşim sebebiyle ortaya çıkan konular sıklıkla karmaşık, açı uçlu, etik-ahlaki durum içeren ve çelişkili sosyobilimsel konulardır [SBK] (Kolsto, 2001; Nielsen, 2012, Sadler, 2004; Sadler \& Zeidler, 2005; Walker \& Zeidler, 2007). Bilimsel alandaki hızlı gelişmeler, SBK şeklinde bahsedilen toplumdaki pek çok ikilemin yaşanmasına neden olmuştur (Topçu, Muğaloğlu \& Güven, 2014).

SBK net olmayan, basit olmayan ve tek çözümlü olmayan, tartı̧̧maya açık bilimsel ve günlük hayatla bağlantılı güncel konuları kapsamaktadır (Kolsto, 2001; Sadler, 2004). SBK doğas1 gereği tartışmalıdır ve çözümünde bireylerin ahlaki ve etik kaygılarının göz önünde bulundurması gerekmektedir (Zeidler \& Nichols, 2009). Bir konunun SBK olması için iki şartı sağlaması gerekir. Birincisi fen bilimlerini içeren bir konu olması, ikincisi ise konunun toplum yaşamında önem arz etmesidir (Sadler \& Zeidler, 2005). Bu anlamda fen bilimlerinin önemi kaçınılmazdır. Fen bilimleri eğitiminde genel amaç bireyin bilimdeki, teknolojideki ilerlemeleri takip etmelerini ve fen konularını öğreterek fen okuryazarı olmalarını sağlamaktır (Albe, 2008; Kolsto, 2006; Walker \& Zeidler, 2007). Fen bilimleri eğitiminde bir diğer amaç ise, bilimsel okuryazarlık ile insanların bilimle ilgili kişisel veya toplumsal olaylar üzerine karar verebilme yetilerini kazanmalarını sağlamaktır (Roberts, 2007). İnsanlar bilimsel bir konuyu bölgesel ve küresel yönden değerlendirerek karar vermektedir. Bu konular SBK şeklinde tanımlanır (Sadler, 2004).

SBK çoğunlukla klonlama, kök hücreler ve genetiği değiştirilmiş gıdalar (GDO) vb. biyoteknoloji konuları olabilmektedir (Sadler \& Zeidler, 2005). Biyoteknoloji konuları, son zamanlarda yaşamımızda aktif bir biçimde rol oynayan önemli teknolojik ve bilimsel ilerlemelerden biridir (Pardo, Midden \& Miller, 2002). Biyoteknolojin uygulama alanları içerisinde kök hücre uygulamaları da yer almaktadır. Kök hücre, kendini devamlı yenileyebilen ve değișik dokulara farklılaşabilen hücreler olarak tanımlanmaktadır (Fortier, 2005). Kök hücre farklı kanser türleri ve çok sayıda hastalığın tedavisinde umut 1şı̆̆ı olmaktadır. Ayrıca kök hücre, hastalıkların mekanizmalarının ortaya çıkarılması ile ilgili çalışmalar için de çok önemlidir (Thieman \& Palladino, 2013).

Alanyazın incelendiğinde çoğunlukla araştırmalarda, fen eğitiminde fen okuryazarı bireylerin yetiştirilmesinde SBK'ların önemli olduğu belirtilmektedir (Zeidler \& Sadler, 2011). Birçok araştırmacı fen bilimleri dersi kapsamında SBK'lara yer verilmesinin önemini vurgulamıştır (Driver, Newton \& Osborne, 2000; Kolsto, 2001; Topçu vd., 2014). Ülkemizde fen eğitimi üzerine yapılan araştırmalarda da fen okuryazarı insanlar yetiştirmede SBK'nın önemi belirtilmiştir (Özdem, Demirdöğen, Yeşiloğlu \& Kurt, 2010; Öztürk \& Türkoğlu \& Düşüngülü, 2018; Yerdelen, Cansiz, Cansiz \& Akcay, 2018). Literatürde çeşitli eğitim seviyelerinde kök hücre ile ilgili araştırmalar da yapılmıştır. Örneğin, Keleş (2018) çalışmasında kök hücreye ilişskin seminerlerinin fen bilimleri lisans öğrencilerinde bilişsel yapıya etkisini belirlemeye çalışmıştır. Gürkan ve Kahraman (2018) çalışmalarında fen bilimleri lisans öğrencilerinin biyoteknoloji ve genetik mühendisliği bilgi düzeyini belirlemiştir. Mevcut çalışmada ise diğer çalışmalardan farklı olarak bir SBK olan kök hücreye ilişkin öğretmen adaylarının algılarını belirlemek hedeflenmiştir.

Bir SBK üzerine tartışmaya katılabilmek veya tartışma sonucuna etki eden çözümleri bulabilmek gibi kazanımların fen okuryazarlığının çok önemli öğeleri olduğu söylenebilir. Bu nedenle ortaokul, lise ve üniversite öğrencilerinin bu kazanımları elde edebilmeleri için fen 
eğitiminde SBK'lara yer verilmelidir (Sadler \& Zeidler, 2005). Çünkü, insanların hayatlarıyla ilgili son derece önemli olan bu tür konular hakkında bilgilendirilmesi ancak kapsamlı bir eğitim ile sağlanabilir. Bu durumda geleceğin fen bilimleri öğretmenleri olacak adayların hizmet öncesi öğretmen eğitimi sürecinde biyoteknoloji konusunda geniş bilgiye sahip olmaları ve farkındalık kazanmaları özel bir önem içermektedir. Gelecek nesillere aktarılacak bilgilerin zincirleme etkisinin oluşturulabilmesi için öğretmenlere büyük görevler düşmekte; ilgili öğretmenlerin ise lisans eğitimleri sırasında henüz öğretmen adayı oldukları süre içerisinde biyoteknoloji konusunda yeterli donanıma sahip olmaları gerekmektedir. Mevcut çalışma, SBK'lara dahil olan biyoteknoloji içerisindeki kök hücre konusuna ilişkin, fen bilimleri öğretmen adaylarının algılarının belirlenmesi açısından önemli görülmüştür. Bu kapsamda çalışmada, fen bilimleri öğretmen adaylarının biyoteknoloji konularından kök hücreye yönelik algılarının belirlenmesi amaçlanmıştır. Bu amaca yönelik olarak çalışmanın problem cümlesi "Fen bilimleri öğretmen adaylarının kök hücreye yönelik algıları nedir?" şeklindedir. Belirtilen problem cümlesine ilişkin aşağıdaki sorulara yanıt aranmaya çalışılmıştır:

1. Fen bilimleri öğretmen adaylarının cinsiyete göre kök hücreye yönelik algıları arasında istatistiksel olarak anlamlı bir fark var midır?

2. Fen bilimleri öğretmen adaylarının sınıf düzeyine göre kök hücreye yönelik algıları arasında istatistiksel olarak anlamlı bir fark var midır?

3. Fen bilimleri öğretmen adaylarının kök hücreye yönelik bilgi kaynakları nelerdir?

\section{Yöntem}

\subsection{Araştırma Modeli}

Bu çalışmada nicel araştırma yönteminden tarama modeli kullanılmıştır. Nicel araştırma her bir kademesi önceden planlanarak oluşturulan bir araştırma yöntemi olarak tanımlanır (Şimşek \& Yıldırım, 2000). Genel çalışma prensibi verilerin sayısal değerlerle ifade edilmesine ve ölçülebilmesine dayanmaktadır. Tarama modeli, fazla sayıda bireyden oluşan evren hakkında genel bir bilgi elde etmek amaciyla örnek ya da örnekleme uygulanan modeldir. Aynı zamanda tarama modeli, geçmişte ya da halen var olan bir durumu betimlemeyi amaçlayan araştırmalardır (Karasar, 2004). Çalışma, genel tarama modellerinden ilişkisel tarama modelinin kullanıldığı bir çalışmadır. İliş̧kisel tarama modelleri, en az iki değişken arasında birlikte değişim varlığını ve/veya ne düzeyde bir ilişki olduğunu belirlemeyi amaçlayan araştırma modelidir (Karasar, 2004).

\section{2. Çalışmanın Örneklemi}

Çalışmanın örneklemini, İç Anadolu Bölgesindeki bir devlet üniversitesinin Eğitim Fakültesi Fen Bilgisi Eğitimi programında 2018-2019 eğitim öğretim yılı bahar döneminde öğrenim gören olan 1, 2, 3 ve 4. sinıflardan toplam 194 fen bilimleri öğretmen adayı oluşturmaktadır. Tablo 1 'de öğretmen adaylarına ait betimsel istatistiklere yer verilmiştir:

Tablo 1. Cinsiyete ve Sınıf Düzeyine Göre Öğretmen Adaylarına Ait Betimsel İstatistikler

\begin{tabular}{cccc}
\hline \multicolumn{2}{c}{ Değişkenler } & Frekans (f) & Yüzde (\%) \\
\hline \multirow{2}{*}{ Cinsiyet } & Kadın & 171 & 88,1 \\
& Erkek & 23 & 11,9 \\
\cline { 2 - 4 } \multirow{4}{*}{ Sinıf } & 1. sinıf & 51 & 26,3 \\
& 2. sinıf & 63 & 32,5 \\
& 3. sinıf & 25 & 12,9 \\
& 4. sinıf & 55 & 28,4 \\
\hline \multicolumn{2}{c}{} & 194 & 100,0 \\
\hline
\end{tabular}


Fen Bilimleri Öğretmen Adaylarının Kök Hücreye Yönelik Algılarının Belirlenmesi

Tablo 1'de sınıf düzeyinde katılımcıların dağılımları incelendiğinde; birinci sınıflardan toplam 51, ikinci sinıflardan toplam 63, üçüncü siniflardan toplam 25 ve dördüncü siniflardan ise toplam 55 öğretmen adayı bulunduğu görülmektedir Araştırmaya 171'i kadın, 23'ü erkek öğretmen adayı olmak üzere toplam 194 öğretmen adayı katılmıştır.

\subsection{Veri Toplama Aracı}

Çalışmada Gönültaş, Ateş ve Taflı (2019) tarafından geliştirilen "Kök Hücre Alg1 Ölçeği (KÖHAÖ)" kullanılmıştır. Ölçek toplamda 19 maddeden oluşmakta olup, 'Kesinlikle Katılmıorum', 'Katılmıyorum', 'Kararsızım', 'Katılıyorum' ve 'Kesinlikle Kat1lıyorum' şeklinde beşli likert tipinde hazırlanmıştır. Ölçeğin Açımlayıcı Faktör Analizi (AFA) ve Doğrulayıcı Faktör Analizi (DFA) Gönültaş ve diğerleri (2019) tarafından yapılmış, DFA sonucunda da elde edilen indeks değerlerinin yüksek derecede kabul edilebilir aralıklarda olduğu görülmüştür. Ölçek iki faktörlü yapıda olup, "Faktör 1: Kök Hücre Tanımı ve Genel Özellikleri" ve "Faktör 2: Kök Hücrenin Tedavide Kullanımı" olarak isimlendirilmiştir. Ölçekte yer alan maddelerin tamamı için hesaplanan Cronbach Alfa güvenirlik katsayıs1 .864 olup, birinci faktör için .824 ve ikinci faktör için .749 olarak tespit edilmiștir. Elde edilen bu katsayılar ölçeğin iyi düzeyde güvenirliğine sahip olduğunu göstermektedir. Aynı zamanda yapılan analizler sonucunda da ölçeğin geçerli ve güvenilir bir ölçme aracı olduğu belirtilmiştir.

Veri toplama aracında ayrıca katlımcılara kök hücre konusundaki bilgi kaynaklarının neler olduğu da sorulmuş, üniversitede kök hücre ile ilgili zorunlu dersimiz oldu, kök hücre ile ilgili bilimsel makaleler okudum, sosyal medyada kök hücre ile ilgili paylaşımları takip ettim şeklindeki bilgi kaynaklarını evet/hayır olarak yanıtlamaları istenmiştir.

\subsection{Veri Toplama Süreci}

Veri toplama aracı 2018-2019 öğretim yılı güz dönemi başında fen bilimleri öğretmen adaylarına uygulanmıştır. Çalışmada veriler araştırmacılar tarafından toplanmıştır. Her sınıf için araştırmacılar tarafından belirlenen uygun saatlerde öğretmen adaylarına ölçeğin uygulaması yapılmış, ölçeği yanıtlamaları için öğretmen adaylarına 15 dakika süre verilmiştir. Tüm verilerin toplanması aynı gün içerisinde gerçekleştirilmiştir. Öğretmen adaylarının uygulama süresince istekli, gönüllü olmalarına önem verilmiştir. Veriler toplandıktan sonra teker teker incelenmiş ve eksik veri olmadığı belirlenen 194 ölçekten elde edilen veriler önce excel programına girilmiş, ardından uygun istatistik programına aktarılarak uygun analizler gerçekleştirilmiştir.

\subsection{Verilerin Analizi}

Verilerin analizinde frekans, yüzde ve ortalama hesaplanmış ve dağılımın özellikleri ortaya konulmuştur. Fen bilimleri öğretmen adaylarının kök hücre algıları arasındaki ilişkinin incelenmesi için ölçekteki her bir maddenin aritmetik ortalaması, alınan en yükssek ve en düşük puanlar hesaplanmıştır. Bu anlamda ölçekten alınabilecek en az puan 19 iken, en yüksek puan 95 olarak belirtilmiştir. Normal dağılım şartının sağlandığı belirlendikten sonra öğretmen adaylarının kök hücreye ilişkin algılarının cinsiyet ve sınıf düzeyi değişkenlerine göre analizlerinde sırasıyla bağımsız t-testi ve tek yönlü ANOVA kullanılmıştır. Öğretmen adaylarının kök hücre konusuyla ilgili bilgi sahip oldukları kaynaklara ilişkin elde edilen verilerin ise frekansları hesaplanarak tablo halinde sunulmuştur.

\subsection{Etik Kurul İzin}

Yapılan bu çalışmada, 2020 yılı öncesi araştırma verileri kullanılmış olup, bu nedenle Etik Kurul İzni alınmamıştır. Çalışmada "Yükseköğretim Kurumları Bilimsel Araştırma ve Yayın 
Etiği Yönergesi” kapsamında uyulması belirtilen tüm kurallara uyulmuş ve yönergenin ikinci bölümünde yer alan "Bilimsel Araştırma ve Yayın Etiğine Aykırı Eylemler"den hiçbiri gerçekleştirilmemiştir. Belirlenen öğretmen adayları çalışmaya gönüllük esasına göre dahil edilmiştir. Ayrıca katılımcılara çalışmanın sonuçlarının bilimsel yayınlarda sunulacağı ifade edilmiş olup, yapılacak olan yayınlarda kimliklerinin kesin olarak gizli tutulacağı söylenmiş ve onayları alınmıştır.

\section{Bulgular}

Fen bilimleri öğretmen adaylarının ölçekteki puanlarının aritmetik ortalamaları, minimum ve maksimum değerleri hesaplanarak algı düzeyleri belirlenmiş, elde edilen veriler Tablo 2'de belirtilmiştir:

Tablo 2. Fen Bilimleri Adaylarının Kök Hücre Algılarına Ait Betimsel İstatistik Sonuçları

\begin{tabular}{lcccc}
\hline & Frekans & Minimum & Maximum & Ortalama \\
\hline Toplam & 194 & 38,00 & 87,00 & 65,80 \\
\hline
\end{tabular}

Tablo 2'ye göre ölçekten alınan en düşük puan 38, alınan en yüksek puan ise 87'dir. Ortalama puan ise 65,80 'dir. Elde edilen puan ortalaması öğretmen adaylarının kök hücre alg1 düzeylerinin yeterli olduğunu ancak çok iyi seviyede olmadığını belirtmektedir.

Fen bilimleri öğretmen adaylarının, cinsiyete göre kök hücreye ilişkin algıları arasında anlamlı bir farklılık olup olmadığını tespit etmek için yapılan bağımsız örneklem t-testi sonuçları Tablo 3 'te yer almaktadır:

Tablo 3. Fen Bilimleri Öğretmen Adaylarının Kök Hücre Algıları ile Cinsiyet Değişkeni Arasındaki İlişkiye Ait Bağımsız t-Testi Sonuçları

\begin{tabular}{lclcccc}
\hline & Cinsiyet & Ortalama & ss & t & df & $\mathrm{p}$ \\
\hline \multirow{2}{*}{ Test sonucu } & Erkek & 3,4874 &, 37244 &, 333 & 192 &, 739 \\
& Kadın & 3,4601 &, 33409 & & & \\
\hline
\end{tabular}

Tablo 3 incelendiğinde, yapılan bağımsız örneklem t-testi sonucunda, fen bilimleri öğretmen adaylarının cinsiyete göre kök hücre algıları arasında anlamlı farklılık olmadığ 1 görülmektedir [t $(192)=.333, \mathrm{p}>.05]$.

Araştırmada diğer bir değişken olarak fen bilimleri öğretmen adaylarının kök hücre konusundaki algılarında sınıf düzeyine göre anlamlı fark olup olmadığı irdelenmiştir. Buna göre yapılan tek yönlü varyans analizi (One-Way ANOVA) sonuçları Tablo 4'te belirtilmiştir:

Tablo 4. Fen Bilimleri Öğretmen Adaylarının Kök Hücre Algıları ile Sınıf Değişkeni Arasındaki İlişkiye Ait ANOVA Testi Sonuçları

\begin{tabular}{lccccc}
\hline Varyans Kaynağ1 & $\mathrm{N}$ & Kareler Toplamı & Kareler Ort. & $\mathrm{F}$ & $\mathrm{p}^{*}$ \\
\hline Gruplar Arası & 3 & 1,439 &, 480 & 3,704 &, 013 \\
Gruplar İçi & 190 & 24,612 &, 130 & & \\
Toplam & 193 & 26,051 & & & \\
\hline
\end{tabular}
$* \mathrm{p}<, 05$

Tablo 5'te görüldüğü gibi, ANOVA testi sonucunda sinıf düzeylerine göre fen bilimleri öğretmen adaylarının kök hücre ile ilgili algıları arasında anlamlı derecede farklılık olduğu belirlenmiştir $\left[\mathrm{F}_{(3,190)}=3.704, \mathrm{p}<.05\right]$. 
Fen Bilimleri Öğretmen Adaylarının Kök Hücreye Yönelik Algılarının Belirlenmesi

Hangi gruplar arasında anlamlı farkın olduğunun ortaya konması amacıyla post-hoc testi uygulanmıştır. Elde edilen veriler Tablo 5'de belirtilmiştir:

Tablo 5. Fen Bilimleri Öğretmen Adaylarının Kök Hücre Algıları ile Sınıf Değişkeni Arasındaki İlişkiye Ait LSD Testi Sonuçları

\begin{tabular}{|c|c|c|c|c|}
\hline & (I) sinif & (J) sinif & Ortalama Fark (I-J) & $\mathrm{p}$ \\
\hline \multirow{12}{*}{ LSD } & \multirow{3}{*}{ 1.sinif } & 2. Sinif &, 08797 & ,196 \\
\hline & & 3. Sinif & , 16182 &, 067 \\
\hline & & 4. Sinif &,- 08699 &, 215 \\
\hline & \multirow{3}{*}{ 2.sinif } & 1. Sinıf &,- 08797 & , 196 \\
\hline & & 3. Sinıf &, 07385 & ,386 \\
\hline & & 4. Sinif &,$- 17495^{*}$ & 009 \\
\hline & \multirow{3}{*}{ 3.sinif } & 1. Sinif &,- 16182 &, 067 \\
\hline & & 2. Sinıf &,- 07385 & ,386 \\
\hline & & 4. Sinif &,$- 24880^{*}$ & ,005 \\
\hline & \multirow{3}{*}{ 4.sinıf } & 1. Sinif &, 08699 & ,215 \\
\hline & & 2. Sinif &, $17495^{*}$ & ,009 \\
\hline & & 3. Sinif & $24880^{*}$ &, 005 \\
\hline
\end{tabular}

Tablo 5'te görüldüğü gibi, fen bilimleri öğretmen adaylarının kök hücreye yönelik algılarında dördüncü sınıf ile ikinci sınıf arasında ve dördüncü sınıfla üçüncü sınıf arasında farklılık tespit edilmiștir. Her iki durumda da dördüncü sınıf öğretmen adayları lehine bir farklılık belirlenmiştir $\left(\overline{\mathrm{X}}_{4}>\overline{\mathrm{X}}_{2}, \overline{\mathrm{X}}_{4}>\overline{\mathrm{X}}_{3}, \mathrm{p}<.05\right)$.

Fen bilimleri öğretmen adaylarının kök hücre konusundaki bilgi kaynaklarının neler olduğu sorusuna ilișkin elde edilen veriler Tablo 6' da belirtilmiștir:

Tablo 6. Fen Bilimleri Öğretmen Adaylarının Kök Hücre Konusundaki Bilgi Kaynakları

\begin{tabular}{llcc}
\hline Bilgi Kaynağ1 & & Frekans (f) & Yüzde (\%) \\
\hline \multirow{2}{*}{$\begin{array}{l}\text { Üniversitede kök hücre ile ilgili zorunlu } \\
\text { dersimiz oldu. }\end{array}$} & Hayır & 185 & 95,4 \\
\cline { 2 - 4 } & Evet & 9 & 4,6 \\
\cline { 2 - 4 } & Toplam & 194 & 100,0 \\
\hline \multirow{2}{*}{$\begin{array}{l}\text { Kök hücre ile ilgili bilimsel makaleler } \\
\text { okudum. }\end{array}$} & Hayır & 147 & 75,8 \\
\cline { 2 - 4 } & Evet & 47 & 100,0 \\
\cline { 2 - 4 } $\begin{array}{l}\text { Sosyal medyada kök hücre ile ilgili } \\
\text { paylaşımları takip ettim. }\end{array}$ & Hayır & 194 & 76,8 \\
\cline { 2 - 4 } & Evet & 194 & 23,2 \\
\cline { 2 - 4 } & Toplam & & 100,0 \\
\hline
\end{tabular}

Tablo 6'ya göre, araştırmada yer alan katılımcılardan üniversite ders programında kök hücre ile ilgili zorunlu ders almayanların sayısının alanlardan, kök hücreyle ilgili bilimsel makale okumayanların sayısının okuyanlardan ve sosyal medyada kök hücre ile ilgili paylaşımları takip etmeyenlerin sayısının edenlerden yüksek olduğu görülmektedir.

\section{Tartışma ve Sonuçlar}

Bu çalışma, SBK'lara dahil olan biyoteknoloji içerisindeki kök hücre konusuna ilişkin fen bilimleri öğretmen adaylarının algılarının belirlenmesi amacıyla yapılmıştır. Araştırmanın sonucunda fen bilgisi öğretmen adaylarının cinsiyetlerinin kök hücre algılarına etkisi olmadığ sonucuna ulaşılmıştır. Bu sonuç doğrultusunda, kadın ve erkeklerin kök hücre konusuna yönelik ilgilerinin benzer seviyede olduğu için bu konuya yönelik algılarının da benzer seviyede olduğu düşünülmektedir. Literatürde yapılan çalışmaların genellikle SBK'da tutum üzerine olduğu 
görülmüş ve cinsiyete göre incelendiğinde tutumlarda anlamlı farklılık görülmediği belirlenmiştir (Soğukpınar, 2019; Uysal, Cebesoy \& Karışan, 2018). Benzer şekilde mevcut çalışmada da algıda cinsiyete göre bir farklılığın belirlenmediği tespit edilmiştir.

Çalışma sonucunda diğer bir değişken olan sınıf düzeyine göre fen bilgisi öğretmen adayların kök hücre algılarına ilişkin anlamlı düzeyde dördüncü sınıf fen bilgisi öğretmen adayları lehine bir farklılık olduğu sonucuna ulaşılmıştır. Öğretmen adaylarının son sınıfta aldıkları 'Biyolojide Özel Konular' dersi kapsamında kök hücre konusunun da yer alabileceği düşünüldügünden bu konuya olan meraklarının ve araştırmalarının daha fazla olabileceği düşünülmektedir. $\mathrm{Bu}$ anlamda ilgili bulguların dördüncü sınıf öğrencileri lehine olması beklenebilir bir sonuçtur. Ayrıca genel olarak sınıf düzeyi değişkeninde, maddelerin aritmetik ortalamasına göre fen bilimleri öğretmen adaylarının kök hücre konusuna ilişkin algılarının ortalamanın üzerinde olduğu tespit edilmiştir.

Bilgi kaynakları açısından bakıldığında, fen bilimleri öğretmen adaylardan üniversitede kök hücre ile ilgili zorunlu ders almayanların sayısının alanlardan, kök hücreyle ilgili bilimsel makaleler okumayanların sayısının okuyanlardan ve sosyal medyada kök hücre ile ilgili paylaşımları takip etmeyenlerin sayısının edenlerden yüksek olduğu sonucuna ulaşılmıştır. Genel olarak ilgili literatür incelendiğinde, çeşitli eğitim düzeyleri üzerine yapılan birçok SBK çalışmaları mevcuttur. Keleş (2018) çalışmasında kök hücreyi konu alan seminerlerin fen bilgisi öğretmen adaylarının kök hücre konusuna ilişkin bilişsel yapılarına etkisini tespit etmeye çalışmıştır. Bu anlamda çalışmanın, benzer katılımcı grubu içermesi ve kök hücre konusuna odaklanması açısından mevcut çalışma ile ilişkili olduğu söylenebilir. Topçu (2008) araştırmasında fen bilimleri öğretmen adaylarının sosyobilimsel konular üzerine kritik düşünme yeteneklerini çalışmıştır. Sönmez (2015) araştırmasında fen bilimleri öğretmenlerinin sosyobilimsel konularda kullandıkları öğretimleri tespit etmeye çalışmıştır. Saad, Baharom ve Mokhsein (2017) araştırmalarında fen bilimleri lisans öğrencilerinin sosyobilimsel konulara yönelik bilimsel akıl yürütme düzeyini değerlendirmiştir. Gürkan ve Kahraman (2018) çalışmasında fen bilimleri öğretmen adaylarının sosyobilimsel konulardan olan biyoteknoloji ve genetik mühendisliği bilgi seviyelerinin sınıf düzeyine göre farklılaştığını tespit etmiştir. Taşpınar (2011) tarafından ele alınmış olup, sosyobilimsel tartışma destekli sağlık eğitimi etkinliklerin, sağlıkla ilgili içerik bilgi seviyelerinin yapılandırmacı yaklaşıma kıyasla arttırdığı yönündedir. Kara (2012) çalışmasında biyoloji öğretmen adaylarının, sosyobilimsel konular öğretimine yönelik algılarını inceleyerek SBK öğretiminde kişisel yeterliliklerinin 1lımlı olduğunu tespit etmiştir. Sezer (2017) çalışmasında öğretmenlerin sosyobilimsel konular hakkında bilgi kaynaklarının önemli bölümünü sosyal medyadan edindiğini belirtmiştir. Belirtilen çalışmalarda SBK'ların öneminin vurguladığı görülmüştür. Bu araştırma da, öğretmen adaylarının SBK'ya yönelik algılarını etkileyecek olan çeşitli faktörler ele alınarak, bunlara yönelik farklılığın belirlenmesi açısından önem taşımaktadır. Bu anlamda SBK öğretimine ilişkin çalışmalar yapan araştırmacılara alternatif bir örnek olabilir.

Mevcut çalışmada sadece nicel araştırma yöntemi kullanılarak buna uygun bir veri toplama aracıyla öğretmen adaylarının algıları belirlenmiştir. İleriki çalışmalarda sınıf gözlemleri ve mülakatlar gibi nitel araştırma yöntemleri kullanılarak öğretmen adaylarının SBK'ya yönelik algıları derinlemesine incelenebilir. Fen Bilimleri Dersi Öğretim Programı'ndaki SBK'lar, öğretmenlerin öğretimde kullanmalarını kolaylaştıracak şekilde vurgulanabilir ve bunlar öncelikle öğretmen adaylarına lisans eğitiminde ilgili derslerde kazandırılabilir.

\section{Kaynaklar}

Albe, V. (2008). Students' positions and considerations of scientific evidence about a controversial socioscientific issue. Science ve Education, 17, 805-827. 
Fen Bilimleri Öğretmen Adaylarının Kök Hücreye Yönelik Algılarının Belirlenmesi

Babacan, M. A. (2017). Sosyobilimsel konulardaki etkinliklerin yedinci sinıf ögrencilerinin eleştirel düşünme becerilerine etkisi (Yayınlamamış yüksek lisans tezi). Ömer Halis Demir Üniversitesi Eğitim Bilimleri Enstitüsü, Niğde.

Driver, R., Newton, P., \& Osborne, J. (2000). Establishing the norms of scientific argumentation in classrooms. Science Education, 84, 287-312.

Fortier, L. A. (2005). Stem cells: Classifications, controversies, and clinical applications. Veterinary Surgery, 34, 415-423. doi:10.1111/j.1532-950X.2005.00063.x

Gönültaş, M., Ateş, A., \& Taflı, T. (2019). Kök hücre algı ölçeği geliştirme çalışması. Uluslararası Sosyal Araştırmalar Dergisi, 12(68), 889-897.

Gürkan, G., \& Kahraman, S. (2018). Knowledge levels of preservice science teachers about biotechnology and genetic engineering. Karaelmas Journal of Educational Sciences, 6, 25-39.

Kara, Y. (2012). Pre-service biology teachers' perceptions on the instruction of socio-scientific issues in the curriculum. European Journal of Teacher Education, 35(1), 111-129.

Karasar, N. (2004). Bilimsel araştırma yöntemi. Ankara: Nobel Yayın Dağıtım.

Keleş, P. (2018). Kök hücre konulu seminerin fen bilgisi öğretmen adaylarının bilişsel yapılarına etkisi. Uluslararası Eğitim Bilim ve Teknoloji Dergisi, 4(1), 41-57.

Kolsto, S. D. (2001). Scientific literacy for citizenship: Tools for dealing with the science dimension of controversial socioscientific issues. Science Education, 85, 291-310.

Kolsto, S. D. (2006). Patterns in students' argumentation confronted with a risk focused socio scientific issue. International Journal of Science Education, 28, 1689-1716.

Nielsen, J. A. (2012). Arguing from Nature: The role of 'nature' in students' argumentations on a socio-scientific issue. International Journal of Science Education, 34, 723-744.

Özdem, Y., Demirdöğen, B., Yeşiloğlu, N., \& Kurt, M. (2010). Farklı branşlardaki alan öğretmenlerinin sosyal yapılandırıcı yaklaşımla bilim anlayışlarının geliştirilmesi. Ahi Evran Üniversitesi Kırşehir Eğitim Fakültesi Dergisi, 11(4), 263-292.

Öztürk, Z., Türkoğlu, A., N., \& Düşüngülü, F. (2018). Toplam kalite yönetiminin örgütsel vatandaşlık davranışı ile ilişkisi. Hitit Üniversitesi Sosyal Bilimler Enstitüsü Dergisi, 11(3), 1727-1744. doi: 10.17218/hititsosbil.427868

Pardo, R., Midden, C., \& Miller, J. D. (2002). Attitudes toward biotechnology in the European Union. Journal of Biotechnology, 98, 9-24.

Roberts, D. A. (2007). Scientific literacy/science literacy. In S. K. Abell \& N. G. Lederman (Eds.), Handbook of research on science education (pp. 729-780). Mahwah, NJ: Lawrence Erlbaum Associates.

Saad, M. I. M., Baharom, S., \& Mokhsein, S. E. (2017). Scientific reasoning skills based on socio-scientific issues in the biology subject. International Journal of Advanced and Applied Sciences, 4(3), 13-18.

Sadler, T. D. (2004). Informal reasoning regarding socioscientific issues: A critical review of research. Journal of Research in Science Teaching, 41(5), 513-536.

Sadler, T. D., \& Zeidler, D. L. (2005). Patterns of informal reasoning in the context of socioscientific decision making. Journal of Research in Science Teaching, 42(1), 112138. 
Sezer, K. (2017). Görev yapan ve atanmamış fen bilimleri ögretmenlerinin sosyobilimsel konularla ilgili öz yeterlilik ve tutumlarının belirlenmesi (Yayınlamamış yüksek lisans tezi). On Dokuz Mayıs Üniversitesi Eğitim Bilimleri Üniversitesi, Samsun.

Soğukpınar, R. (2019). Fen bilgisi ögrretmen adaylarının genetik ve biyoteknolojiye yönelik tutumlarının incelenmesi (Yayınlamamış yüksek lisans tezi). Adnan Menderes Üniversitesi Fen Bilimleri Enstitüsü Matematik ve Fen Bilimleri Eğitimi Anabilim Dalı, Aydin.

Sönmez, A. (2015). Fen bilimleri öğretmenlerinin epistemolojik inanç sistemleri ve sosyobilimsel konular hakkında yaptıkları ögretimler arasındaki ilişkinin belirlenmesi (Yayınlamamış doktora tezi). Abant İzzet Baysal Üniversitesi Eğitim Bilimleri Enstitüsü, Bolu.

Şimşek, H., \& Yıldırım, A. (2000). Sosyal bilimlerde nitel araştırma yöntemleri (2. baskı). Ankara: Seçkin Yayıncılık.

Taşpınar, P. (2011). Sosyobilimsel tartışma teknikli sağlık eğitimi etkinliklerinin ilköğretim 5. sinıf ögrencilerinde sağllk bilincinin ve içerik bilgisinin gelişimine etkisi. (Yayınlanmamış yüksek lisans tezi). Marmara Üniversitesi, Eğitim Bilimleri Enstitüsü, İstanbul.

Thieman W. J., \& Palladino M. A. (2013). Introduction to biotechnology. Benjamin Cummings, San Francisco.

Topçu, M. S., Muğaloğlu, Z. E., \& Güven, D. (2014). Fen eğitiminde sosyobilimsel konular: Türkiye örneği. Kuram ve Uygulamada Eğitim Bilimleri Dergisi, 14(6), 2327-2348.

Topçu, M. S. (2008). Fen ögretmen adaylarının sosyobilimsel konular hakkındaki kritik düşünme yetenekleri ve bu yetenekleri etkileyen faktörler (Yayınlanmamış doktora tezi). Orta Doğu Teknik Üniversitesi, Sosyal Bilimler Enstitüsü, Ankara.

Uysal, E., Cebesoy, Ü. B., \& Karışan, D. (2018). Fen bilgisi öğretmen adaylarının genetik uygulamalarına yönelik tutumlarının çeşitli değişkenler açısından incelenmesi. Batı Anadolu Ĕ̈itim Bilimleri Dergisi, 9, 1-14.

Walker, K., \& Zeidler, D. L. (2007). Promoting discourse about socioscientific issues through scaffolded inquiry. International Journal of Science Education, 29, 1387-1410.

Yerdelen, S., Cansiz, M., Cansiz, N., \& Akcay, H. (2018). Promoting preservice teachers' attitudes toward socioscientific issues. Journal of Education in Science, Environment and Health (JESEH), 4(1), 1-11. DOI:10.21891/jeseh.387465

Zeidler, D. L., \& Nichols, B. H. (2009). Socioscientific issues: Theory and practice. Journal of Elementary Science Education, 21(2), 49-58.

Zeidler, D. L., \& Sadler, D. L. (2011). An inclusive view of scientific literacy: Core issues and future directions of socioscientific reasoning. In C. Linder, L. Ostman, D. A. Roberts, P. Wickman, G. Erickson \& A. MacKinnon (Eds.), Promoting scientific literacy: Science education research in transaction (pp. 176-192). New York: Routledge/Taylor and Francis Group.

\section{EXTENDED ABSTRACT}

\section{Introduction}

The place of science in society has been increasing significantly while science and technology have been developing rapidly in recent times. The issues that appear due to the interaction 
Fen Bilimleri Öğretmen Adaylarının Kök Hücreye Yönelik Algılarının Belirlenmesi

between science and technology are often complex, open-ended, ethical-moral and contradictory sociological issues [CSI]. One of the important technological and scientific advances that have played an active role in our lives recently is biotechnology in science. There are stem cell applications in biotechnology applications. Stem cells are defined as structures that can continuously renew theirselves. Stem cells are a source of hope in the treatment of different types of cancer and many diseases. Hence, stem cells are very important for studies on revealing mechanisms of diseases. Having science literacy about these issues that have social importance are important. Because of this reason, these subjects should be included in science education so that secondary school, high school and university students can achieve these achievements. Therefore, it has been considered important to determine the perceptions of science teacher candidates regarding the stem cell topic in biotechnology, which is included in CSI's.

\section{Purpose}

Informing individuals about their health can be provided through a comprehensive education. In this case, it has a special importance to candidates, who will be science teachers of the future, to have extensive knowledge about biotechnology during their education and gain awareness. With this work, science teacher candidates are suppose to determine the biotechnology issues for stem cells. For this purpose, the problem statement of the study was determined as; "What are the perceptions of science teacher candidates for stem cells?"

\section{Method}

In order to determine the perceptions of science teacher candidates towards stem cells, a survey model from quantitative research method was used. The sample of the study consists of 194 science teacher candidates who are studying in the 1st- 4th grades in the Science Education Program of the Faculty of Education of a public university in the Central Anatolia Region.

"Stem Cell Perception Scale (SCPS)" was used as data collection tool in the study. The scale consists of 19 items in total, and was prepared in the form of a five-point Likert type, "I definitely disagree", "I disagree", "I am indecisive", "I agree" and "I definitely agree". In the analysis of the data, frequency, percentage and average were calculated and the properties of the distribution were revealed. The arithmetic mean of each item in the scale was taken to examine the relationship between science teacher candidates' stem cell perceptions. In addition, the highest and lowest scores that could be obtained were calculated. According to the results that could be obtained, the minimum score that people could get from the scale is 19 while the highest score is specified as 95 . After determining that the normal distribution condition was met, independent t-test and one-way ANOVA were used in the analysis of the teacher candidates' perceptions of stem cells according to gender and grade level variables, respectively.

\section{Findings}

Perception levels of science teacher candidates were determined by calculating the arithmetic averages, minimum and maximum values of the scores in the scale. The lowest score and the highest score obtained from the scale are 38 and 87, respectively. Due to the average score which is 65.80 it is understood that the teacher candidates' stem cell perception levels are sufficient but not at a very good level. Independent sample t-test was applied to determine whether there is a significant difference between the science teacher candidates' perceptions of stem cells by gender. According the result of the independent sample t-test applied, it was observed that there were no significant difference between science teacher candidates' stem cell perceptions according to gender $[\mathrm{t}(192)=.333, \mathrm{p}>.05]$. Whether the perceptions of the science teacher candidates about stem cell, which is another variable in the research, differed according 
to the grade level, was determined by using one-way ANOVA. In order to the results of the ANOVA test, a significant difference was determined between the perceptions of science teacher candidates regarding stem cells according to their grade levels $(\mathrm{p}<.05)$. When the average scores of science teacher candidates for stem cells were examined, the difference between the 4th grade and the 2 nd grade, addition to 4th grade and the 3rd grade was found. Post-hoc test was applied to determine the groups that belonged to the statistically significant difference detected as a result of the ANOVA test. In both situations, a difference was determined in favor of 4th graders. Due to the results that were obtained from the study, the information sources of science teacher candidates about stem cells are given below:

$\checkmark$ We had a compulsory course about stem cells at the university.

$\checkmark$ I have read scientific articles about stem cells.

$\checkmark$ I followed the posts about stem cells on social media.

According to the answers given by the participants above, it was determined that the number of those who did not take compulsory courses related to stem cells in the university curriculum was more than those who took the course, while the number of those who did not read scientific articles about stem cells was higher than those who read. In addition to all these, we can tell that the number of people who do not follow the posts about stem cells in social media is less than those who do.

\section{Conclusion and Suggestions}

As a result of the research, it was determined that there is no significant difference in science teachers candidates' stem cell perceptions according to their gender. At this point, the amount of the women and men that are interested in stem cells are at a similar level. Therefore, it can be thought that their perceptions about the subject are at a similar level. When the stem cell perceptions of science teacher candidates were analyzed according to the grade level, a significant difference was determined by the researchers. In this case, it is concluded that there is a difference in favor of 4th grade science teacher candidates. This may be due to the fact that the teacher candidates take the stem cell topic within the scope of the 'Special Topics in Biology' course taken in the final grades. In addition, according to the arithmetic average of the items in the grade level variable in general, the perceptions of 4th grade science teacher candidates about stem cell topic were found to be above the average. When the results obtained in terms of the information sources about the stem cell subject of science teacher candidates were evaluated, the following results were obtained:

$\checkmark$ The amount of the people who did not take compulsory courses related to stem cells in the university curriculum is higher than those who took,

$\checkmark$ The amount of people who do not read scientific articles about stem cells is higher than those who read,

$\checkmark$ The amount of the people who do not follow the posts about stem cells in social media is higher than those who do.

In this research, various factors that will affect teachers candidates' perceptions about CSI are discussed. In this respect, the study is important in terms of determining awareness towards CSI. This work may be an alternative example for researchers who are working on CSI teaching. With the current work, the perceptions of teacher candidates were determined with the data collection tool prepared based on the quantitative research method. Hence, in the future studies, the perceptions of teacher candidates towards CSI can be examined in depth using qualitative research methods such as classroom observations and interviews. Additionally, an inductive 
Fen Bilimleri Öğretmen Adaylarının Kök Hücreye Yönelik Algılarının Belirlenmesi

teaching process and sociological teaching models based on practice can be suggested in teacher education.

\section{Etik Kurul İzin:}

Yapılan bu çalışmada, 2020 yılı öncesi araştırma verileri kullanılmış olup, bu nedenle Etik Kurul İzni alınmamıştır. Çalışmada "Yükseköğretim Kurumları Bilimsel Araştırma ve Yayın Etiği Yönergesi” kapsamında uyulması belirtilen tüm kurallara uyulmuş ve yönergenin ikinci bölümünde yer alan "Bilimsel Araştırma ve Yayın Etiğine Aykırı Eylemlerden" hiçbiri gerçekleştirilmemiştir. Belirlenen öğretmen adayları çalışmaya gönüllük esasına göre dahil edilmiştir. Ayrıca katılımcılara çalışmanın sonuçlarının bilimsel yayınlarda sunulacağı ifade edilmiş olup, yapılacak olan yayınlarda kimliklerinin kesin olarak gizli tutulacağı söylenmiş ve onayları alınmıştır. 